\title{
De ontwerp-Richtlijn Verzekeringsmaatschappijen belicht
}

\author{
Prof. Dr. A. Oosenbrug
}

\section{Inleiding}

Titel 9 Boek $2 \mathrm{BW}$ beval in afdeling 15 specifieke bepalingen omtrent de verslaggeving door verzekeringsmaatschappijen. Mede naar aanleiding daarvan vermeldt al. 1.01.309 van de Richtlijnen van de Raad voor de Jaarverslaggeving $(\mathrm{RJ})$ : 'Op verzekeringsmaatschappijen, beleggingsmaatschappijen en banken zijn specifieke bepalingen van toepassing (...). Deze bepalingen en regelingen alsmede de aard van de bedrijfsactiviteiten kunnen er toe leiden dat bepaalde stellige uitspraken en/of aanbevelingen niet van toepassing kunnen zijn. Voor de desbetreffende organisaties of bedrijfstakken kunnen afzonderlijke Richtlijnen worden gegeven. In afwachting van de totstandkoming daarvan zijn de (ontwerp) Richtlijnen van toepassing, tenzij de aard van de wettelijke regeling en/of de aard van de bedrijfsactiviteiten zich tegen de toepassing van een (ontwerp-)Richtlijn verzet.'

Gegeven de afwijkende aard van de bedrijfsactiviteiten van een verzekeraar en gegeven de (juist daardoor) ruime mate waarin met afdeling 15 wordt afgeweken van de meer algemeen van toepassing zijnde bepalingen, waren de (ontwerp-)Richtlijnen valn de RJ tot voor kort maar in beperkte mate relevant voor verzekeraars. Met de in april 1997 gepubliceerde ontwerp-Richtlijn over de verslaggeving door verzekeringsmaatschappijen is hier verandering in gekomen. In deze bijdrage wordt

Prof. Dr. A. Oosenbrug RA, AAG is bijzonder hoogleraar waarderings- en verslaggevingsvraagstukken van het verzekeringsbedrijf en bijzonder hoogleraar Economie van het verzekeringsbedrijf aan de Erasmus Universiteit Rotterdam en adviseur van de Financiële sector groep van Coopers \& Lybrand NV kritisch stilgestaan bij het in de ontwerp-Richtlijn gestelde. Gezien de omvang hiervan (inclusief 1 bijlage: 60 pagina's), is een integrale behandeling daarvan niet mogelijk. Volstaan wordt met een korte schets van de opzet en van enkele algemene bepalingen en met het kritisch belichten van de als 'vernieuwend' te beschouwen uitspraken. Bovendien ligt het accent - net als in de ontwerp-Richtlijn zelf - op de bepalingen omtrent de beleggingen en de verzekeringstechnische voorzieningen.

\section{Opzet van de ontwerp-Richtlijn}

De ontwerp-Richtlijn volgt de ook in het BW aangehouden structuur, waarin alleen de specifiek voor (her)verzekeratars geldende bepalingen afzonderlijk (in afdeling 15) zijn vastgelegd. De ontwerp-Richtlijn vormt daarmee een aumulling op de in de overige hoofdstukken van de Richtlijnen vastgelegde algemene bepalingen. Die algemene bepalingen gelden daardoor tevens voor verzekeraars, tenzij uit de specifiek voor hen geldende bepalingen het tegendeel blijkt.

In de ontwerp-Richtlijn wordt met name aandacht geschonken aan de waarderings- en resultaatbepalingsgrondslagen voor de beleggingen en de verzekeringstechnische voorzieningen. Daarnaast komen (kort) aan de orde:

- overige activa en overige passiva;

- eigen vermogen;

- baten en lasten, en

- herverzekering. kasstroomoverzicht en geconsolideerde jaarrekening.

De in de Richtlijnen opgenomen oordelen van de RJ zijn te onderscheiden in aumbevelingen en stellige uitspraken. Aanbevelingen brengen een 
voorkeur voor het hanteren van een zekere grondslag tot uitdrukking. zonder dat daarbij alleen de desbetreffende grondslag aanvaardbaar wordt geacht. of een zekere grondslag onalnvaurdbaar wordt geacht. Stellige uitspraken brengen een oordeel tot uitdrukking wilarvan de RJ verwacht dat datar alleen maar van wordt afgeweken indien daarvoor goede gronden zijn. Ook deze stellige uitspraken hebben echter geen wettelijke status en hebben derhalve geen bindende kracht.

\section{Reikwijdte en van toepassing verklaarde voorschriften}

De RJ richt zich met het voorliggende ontwerp op verzekerings- en herverzekeringsmaatschappijen die op grond valn hun rechtsvorm zijn onderworpen aan Titel 9 van Boek 2 BW. Aangezien Nederlandse (her)verzekeraturs krachtens de WTV 1993' de rechtsvorm naamloze vennootschap of onderlinge waarborgmalatschappij moeten hebben. is de ontwerp-Richtijn in beginsel relevant voor alle Nederlandse (her)verzekeraars. Iloudstermaatschappijen die de gegevens consolideren van een verzekeringsgroep of -groepsdeel ${ }^{2}$, vallen tevens binnen de reik wijdte van de ontwerp-Richtlijn.

De wettelijke bepalingen voor de jaarrekening van (her)verzekeralars zijn opgenomen in Titel 9 Boek 2 BW en in een aantal daarop gebaseerde uitvoeringsbesluiten. Krachtens de algemene alanwijzingen voor het invullen van de jaarlijks bij de Verzekeringskamer ( $\mathrm{VK}$ ) in te dienen verslagstaten moet ook de in die verslagstaten op te nemen jaarrekening voldoen aan de bepalingen van Titel 9 Boek 2 BW. Daarnaast moeten de verslagstaten voldoen aan de in de WTV 1993 en de daarop gebaseerde uitvoeringsbesluiten opgenomen bepalingen dienaangaande.' De RI. al. 3.23.110. noemt in dit kader het Besluit technische voorzieningen verzekeringsbedrijf 1994, de beleidsnota Actuariële principes van de Verzekeringskamer en de Regeling maximum rentepercentilges en voorzichtigheidsmarges levensverzekeringsbedriji 1994. De RJ stelt dat het Besluit technische voorzieningen verzekeringsbedrijt ook van toepassing is op de jaarrekening.

Uit een oogpunt van duidelijkheid voor de gebruikers wordt alanbevolen de te publiceren jaarrekening zodanig op te stellen. dat die tevens voldoet aan de voorschriften die gelden voor de te publiceren verslagstaten. ${ }^{4}$ Daarmee worden ook de overige bepalingen inzake de verslaggeving richting de toezichthouder op indirecte wijze aanbevolen voor toepassing in de jaarrekening. Hocwel het desondanks verdedigbaar wordt geacht om voor de jaarrekening en de verslagstaten verschillende waarderings- en resultaatbepalingsgrondslagen te hanteren, gaat het gestelde toch een stap te ver. Zolang het verschil in invalshoek tussen de externe verslaggeving ten behoeve valn het maatschappelijk verkeer en die ten behoeve van de toezichthouder nog tol uitdrukking komı in de waarderings- en resultaatbepalingsvoorschriften. leidt de bedoelde aanbeveling onoverkomelijk tol fricties. De frictie tussen de door de VK gewenste nulstelling van het saldo van de overlopende acquisitiekosten en de voorziening voor levensverzekering en de bedrijfseconomische activeringscriteria is hiervan een concreet voorbeeld. Met een toenemende behoefte bij verzekeralars tot het serieus nemen van de getrouwheidseis enerzijds, en een sterk uitdijende - op solvabiliteitsbewaking en voorzichtigheid gerichte toezichtsregelgeving anderzijds, zal het 'gekunsteld ' mocten voldoen aan de toezichtregels meer en meer gaan knellen en een soepele verdere evolutie van de verslaggevingspraktijk belemmeren. Bovendien staal de gegeven aanbeveling haaks op de mening van de wetgever. die het aan een bedrijfseconomische toezichthouder toekennen van een regelgevende laak op het vlak van de externe verslaggeving juist nadrukkelijk heeft af gewezen.

Dat een tweesporige verslaggeving de duidelijkheid niet ten goede komt (RJ. al. 3.23.110), is dan betreurenswaardig. maar inherent aan de huidige toezichtconstellatie (zie Oosenbrug. 1997: paragraaf 2.3, voor het altematief). Overigens is dit nadeel van een hoog theoretisch gehalte; de (zeldzame) gebruiker die niet slechts kennis neemt van de jaarrekening, maar tevens van de publicatiestaten, is normaliter van een zodanig kaliber dat de bedoelde verschillen voor hem geen probleem zullen vormen.

\section{Beleggingen}

\subsection{Algemeen}

De bcleggingen worden - in aansluiting op de modellen $\mathrm{N}$ en $\mathrm{O}$ van het Besluit modellen jaarrekening - onderscheiden in de categorieën:

- terreinen en gebouwen; 
- groepsmaatschappijen en deelnemingen:

- aandelen, deelnemingsbewijzen en andere nietvastrentende waardepapieren;

- vastrentende beleggingen (obligaties en andere vastrentende waardepapieren. vorderingen uit hypothecaire leningen en vorderingen uit andere leningen):

- belangen in beleggingspools:

- andere finnanciële beleggingen;

- depots bij verzekeraiars;

- beleggingen voor risico vin polishouders en spaarkasbeleggingen.

In de volgende paragrafen wordt ook deze indeling aangehouden.

\subsection{Beleggingen in terreinen en gebouwen}

Krachtens artikel 2:442, vierde lid BW hoefi niet te worden afgeschreven op gebouwen die worden gewaardeerd tegen actuele waarde.

Aanbevolen wordt om gebruik te maken van deze optie. Bij de vaststelling van de actuele waarde mag gebruik worden gemaakt van taxaties door interne taxateurs, hetgeen dan in de toelichting moet worden vermeld.

Ook de in eigen gebruik zijnde gebouwen en terreinen worden als beleggingen beschouwd. Bij de keuze van de waarderingsgrondslag dient dan ook geen onderscheid te worden gemaakt tussen in eigen gebruik zijnde gebouwen en terreinen en andere gebouwen en terreinen.

Op grond van een algemene stellige uitspraak $(R J$, al. 2.02.205) mogen renovatiekosten alleen worden geactiveerd, indien zij leiden tot een walardeverhoging of indien zij het gevolg zijn van wettelijke verplichtingen. Voor de beleggingen in terreinen en gebouwen van verzekeraars wordt dit nader geconcretiseerd tot de eis, dat er sprake moet zijn van een op korte termijn realiseerbaar huurprijsverhogend effect. Waarom deze stelling niet net als de meer algemene stelling de status heeft gekregen van stellige uitspraak, is niet duidelijk. Daarmee blijft in de lucht hangen, of deze nadere concretisering de algemene uitspraak integraal of enkel partieel vervangl. ergo: is de rariteit dat een wettelijke verplichting sec waarde zou geven aan bestedingen nu wel of nict tevens van toepassing voor verzekeralrs? Het verdient alanbeveling om in de definitieve Richtlijn duidelijk tot uitdrukking te brengen dat deze rariteit in elk geval niet geldt voor verzekeraars.
Bij in eigen beheer ontwikkeld onroerend goed mag de alan het actief toerekenbare rente over het vervaardigingstijdvak worden geactiveerd (artikel 2:388. Iweede lid BW). Het gedurende de verslagperiode geactiveerde bedrag moet in de toelichting worden vermeld. Aanbevolen wordt om uit te gaan van de marktrente lijdens de bouw (RI, al. 3.23.207). De technische voorzieningen kunnen in dit kader in alnmerking worden genomen als schulden. De voor de technische voorzieningen geldende rekenrente zal evenwel in het algemeen aanzienlijk lager liggen dan de marktrente voor schulden die de onderneming alangaat.

De stellige uitspraak dat aandelen van of beleggingen in vastgoedfondsen, waarin geen invloed van betckenis op het zakelijke en financiële beleid wordt uitgeoefend, mocten worden gerubriceerd onder de categorie "Aandelen e.d. ', bevestigt enkel hetgeen direct uit de wet volgt. In die zin is deze uitspraak overbodig. Dat de RJ desondanks aandacht besteedt aan dit punt, geeft impliciet aan dat dergelijke participaties blijkbaar niet als 'gewone' aandelen worden ervaren. Helaas wordt dit echter niet expliciet gemaakt. waardoor de kans wordt gemist om hier ook daadwerkelijk (loegevoegde waarde bezittende) consequenties aan te verbinden. Gegeven het afwijkende risico/rendementsprofiel valn participalies in vastgoedfondsen, was het een goede zalak geweest indien een aanbeveling wals opgenomen tol het afzonderlijk vermelden van de gegevens inzake de beleggingen in vastgoedfondsen. ${ }^{5}$

\subsection{Groepsmaarschappijen en deelnemingen}

Omtrent de beleggingen in groepsmaatschappijen en deelnemingen resumeert de RJ slechts de daarop betrekking hebbende wettelijke bepalingen. Nadere richtlijnen of interpretaties worden niet gegeven.

\subsection{Beleggingen in aundelen. deelnemingshewijzen en andere niet-vastrentende waardepapieren}

Overeenkomstig de algemene wettelijke regels voor de waardering van beleggingen van verzekeraars kan ook deze categorie van beleggingen worden gewaardeerd tegen kostprijs of actuele waarde. De RJ beveelt aan om deze beleggingen te waarderen tegen actuele waarde. 


\subsection{Vastrentende beleggingen}

Op grond van artikel 2:443, eerste lid BW mogen de tot de vastrentende beleggingen behorende waardepapieren worden gewaardeerd tegen aflossingswaarde. Is de kostprijs lager dan de aflossingswaarde dan moet het resulterende disagio worden gepassiveerd en gespreid over de (resterende) looptijd in het resultaat worden verantwoord. Een agio mag op gelijksoortige wijze worden verantwoord, doch mag ook ineens ten laste van het resultaat worden gebracht (artikel 2:443, tweede lid BW).

Worden vastrentende waardepapieren tussentijds verkocht binnen het kader van een ruiltransactie, dan mogen positieve en negatieve verschillen tussen de boekwaarde en de verkoopopbrengst in de balans worden opgenomen en gespreid over de resterende looptijd van de verkochte beleggingen in het resultaat worden verantwoord. ${ }^{6}$ Worden de vastrentende waardepapieren gewaardeerd tegen actuele waarde, dan is deze optie niet van toepassing (artikel 2:443, derde lid, tweede zin $\mathrm{BW})$. De RJ interpreteert deze bepaling onterecht aldus dat deze optie alleen van toepassing zou zijn bij een waardering tegen aflossingswaarde (al. 3.23.210, derde blok). Ook bij een waardering tegen verkrijgingsprijs is het toepassen van de amortisatiemethode evenwel mogelijk. Oorspronkelijk was de amortisatiemethode zelfs speciaal gericht op een situatie waarin een waardering tegen verkrijgingsprijs het vertrekpunt vormde (zie Oosenbrug, 1990).

De RJ beveelt aan, om (waar mogelijk) te kiezen voor het gespreid verantwoorden van de bedoelde verschillen. Wordt deze aanbeveling gevolgd, dan ontstaan er op de balans op te nemen en nog te amortiseren verschillen. Worden deze verschillen onder de post Beleggingen opgenomen, zoals in de praktijk nog regelmatig voorkomt (zie bijvoorbeeld Aegon Verzekeringen, 1996, p. 58), dan is er uiteraard geen sprake meer van het tegen aflossingswaarde (respectievelijk het tegen verkrijgingsprijs) op de balans opnemen van de beleggingen. Terecht doet de $R J$, al. 3.23.301, dan ook de stellige uitspraak, dat de nog niet geamortiseerde verschillen onder de overlopende activa c.q. passiva moeten worden opgenomen, en wel afzonderlijk en als één gesaldeerd bedrag. Dit gegeven zijnde, is niet goed duidelijk hoe de verwijzing naar de over rentelasten handelende al. 2.71.304 moet worden geïnterpreteerd, waarin onder meer wordt gesteld dat nog niet toegerekende (dis)agiobedragen in de toelichting moeten worden vermeld. Ook overigens is deze verwijzing overbodig en eerder verwarringwekkend dan verhelderend.

De wetgever heeft zich niet uitgelaten over de wijze waarop de te spreiden resultaten moeten worden geamortiseerd. Theoretisch komt uitsluitend een spreiding op basis van een annuitair aflossingsschema hiervoor in aanmerking ( $\mathrm{COO}$ pers \& Lybrand, 1997, p. 21), waarbij moet worden uitgegaan van de effectieve rentevoet die geldt (gold) op het (oorspronkelijke) beleggingsmoment. Alleen een dergelijk systeem leidt er immers toe dat de resultaatbepaling wordt gebaseerd op effectieve rendementen en dat een oorspronkelijk daaruit voortvloeiend verantwoordingspatroon ook niet meer wordt verstoord door eventuele later plaatsvindende ruiltransacties (dit alles onder het mom 'substance over form'). Hoewel de RJ terecht de aanbeveling doet tot het volgen van de beschreven methodiek (met de huidige stand van de administratieve techniek had dit ook wel een stellige uitspraak mogen zijn!), is de daarvoor gegeven motivatie niet correct.

Als onderbouwing voor het toepassen van de amortisatiemethode in de vorenstaand bedoelde zin, wordt het punt van de matching van baten en lasten aangevoerd. Dit punt kan evenwel per definitie slechts van betekenis zijn, indien en voor zover de verantwoording van baten en lasten ook daadwerkelijk in hun onderlinge samenhang wordt beschouwd, hetgeen niet het geval is. Zou dit wel zijn gebeurd, dan had dit nimmer kunnen leiden tot de thans gehanteerde formuleringen, op grond waarvan er geen voorwaarden worden gesteld aan het mogen toepassen van de amortisatiemethode. Indien de aanvaardbaarheid van deze methode zou zijn gefundeerd op matching (quod non), dan zou de toelaatbaarheid van de amortisatiemethode zich namelijk hebben moeten beperken tot de verwerking van resultaten uit hoofde van met specifieke passiva verbonden beleggingen.

Bovendien geeft het matchingargument binnen het kader van ruiltransacties niet meer dan een 'zwakke rechtvaardigingsgrond voor een partiële toepassing van de amortisatiemethode' (Oosenbrug. 1990, p. 73). Het matchingbeginsel heeft immers in principe betrekking op de lasten- en niet op de batentoerekening en rechtvaardigt uitsluitend de toepassing van de amortisatiemethode 
onder bepaalde omstandigheden. Het argument ter onderbouwing van de amortisatiemethode is niet het matchingargument, malar het al genoemde 'substance over form'-beginsel (zie Oosenbrug (1995), paragraaf 3.2.3).

Leningen $\mathrm{u} / \mathrm{g}$ mogen ook tegen allossingswaarde worden gewaardeerd (artikel 2:443, vierde lid BW). De bepalingen omtrent de toelaalbaarheid van de amortisatiemethode zijn daarentegen niet (expliciet) daarop van toepassing verklaard. Gezien de overeenkomsten in aard en karakter met beleggingen in vastrentende waardepapieren, moet worden aangenomen dat dit een redactionele omissie in de wetlekst is. De stellige uitspraak dat het bepaalde inzake de verwerkingswijze van (dis)agio's bij aan-en verkoop ook voor deze beleggingen geldı, is dan ook volkomen terecht.

Hoewel dit volledig in lijn zou zijn geweest met de ain de wet ten grondslag liggende filosofie. bevat de wet geen bepaling dat ook bij een walardering tegen aflossingswaarde de toelichting de actuele walarde zou moeten vermelden. Met de stellige uitspraak dat de aflossingswaarde binnen dit kader moet worden gezien als een variant op de verkrijgingsprijs ( $R J$, al. 3.23.226), creëert de RJ (op een enigszins gekunstelde wijze) al snog een dergelijke bepaling.

Volkomen terecht wordt de stellige uitspraak gedaan, dal verstrekte actuele-walardeinformatie omtrent vastrentende beleggingen op een goede wijze moet worden toegelicht. teneinde een onjuiste interpretatie te voorkomen. Aangezien verzekeringstechnische verplichtingen normaliter niel op actuele walde worden gewaardeerd, is acluele-waardeinformatie omtrent de (daarmee verbonden ) beleggingen namelijk in het algemeen weinigzeggend.

De actuelc waarde van beleggingen is gelijk aan de marktwaarde. Voor vastrentende beleggingen als hypothecaire leningen en andere leningen bestaat er echter niet altijd een courante markt. Waardering tegen rendementswalarde? ligt dan volgens de RJ voor de hand. Bij de keuze van de te hanteren disconteringsvoeten moet rekening worden gehouden met verschillen in looptijden en debiteurenrisico"s. Desondanks vorm de rendementswaarde in het algemeen slechts een globale indicatie voor de actuele waarde. Het wordt aanbevolen om daar in de toelichting melding van te maken.

\subsection{Belangen in beleggingspools, andere financiele beleggingen en depots bij verzekeraars}

Belangen in beleggingspools doen zich voor indien verzekeraars samenwerken bij de verzekering van pensioenregelingen. terwijl één van de verzekeraars daarbij belast is met het beleggen van de beschikbare middelen. Elke verzekeraar neemt het volgens de opgave van de poolbeheerder bestaande eigen belang op. bij voorkeur op basis van de eigen grondslagen. Ontbreekt de daarvoor benodigde informatie, dan mogen de voor de pool overeengekomen grondslagen worden aangehouden.

De aanbeveling om de andere financiële beleggingen, zoals schatkistpapier, commercial paper en blote eigendommen, te waarderen tegen kostprijs of aflossingswaarde (en dus niet tegen actuele waarde), komt volledig uit de lucht vallen en is ook niet goed plaatsbaar binnen de contexı van het overigens gestelde.

De depots bij verzekeraars moeten afzonderlijk worden opgenomen. Gezien het door het Besluit modellen jaarrekening voorgeschreven model, is deze (stellige) uitspraak feitelijk overbodig.

\subsection{Beleggingen roor risico van polishouders en spacatasheleggingen}

In aanvulling op de uit de wet voortvloeiende bepalingen. wordl aanbevolen om ook de gesepareerde beleggingen - bijvoorbeeld behorende bij collectieve pensioencontracten - hieronder op te nemen. Ook bij die beleggingen ligt het beleggingsrisico immers in beginsel niet bij de verzekeraar.

\subsection{Verantwoording van koersresultaten op beleggingen}

In een bijlage bij de ontwerp-Richtlijn worden voor de belangrijkste beleggingscategorieën de mogelijkheden voor het verwerken van nietgerealiseerde en gerealiseerde resultaten en van waardeverminderingen en van terugnemingen daarvan schematisch weergegeven (zie schema 1). 


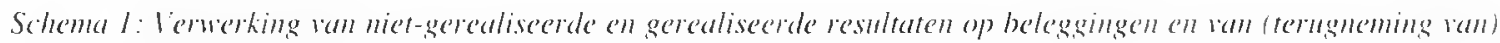
narderermindering ran beleggingen

\begin{tabular}{|c|c|c|c|c|c|c|}
\hline & $\begin{array}{l}\text { Niet-gereali- } \\
\text { serede wins }\end{array}$ & $\begin{array}{l}\text { Nict-gereali- } \\
\text { sered werlices }\end{array}$ & $\begin{array}{l}\text { Gerealiseerde } \\
\text { wimst }\end{array}$ & $\begin{array}{l}\text { Gerealisererd } \\
\text { rerlices }\end{array}$ & $\begin{array}{l}\text { Hearde- } \\
\text { remmindes- } \\
\text { ring }\end{array}$ & 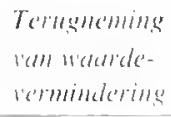 \\
\hline \multicolumn{7}{|l|}{$\begin{array}{l}\text { Beleggingen in } \\
\text { terreinen en gebouwen } \\
\text { en in aandelen }\end{array}$} \\
\hline $\begin{array}{l}\text { - walludering logen } \\
\text { kostprijs }\end{array}$ & - & & in resultatis & in resultalat & in r'esultalal & in resullatat \\
\hline $\begin{array}{l}- \text { Waldidering legen } \\
\text { acluele waludede }\end{array}$ & $\begin{array}{l}\text { in herwatarde- } \\
\text { mangsieserve of } \\
\text { in resultalat }\end{array}$ & 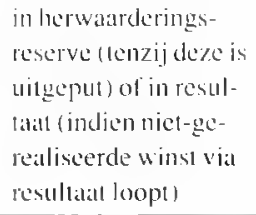 & $\begin{array}{l}\text { in herwalarde- } \\
\text { ringsreserve of } \\
\text { in resultatit }\end{array}$ & 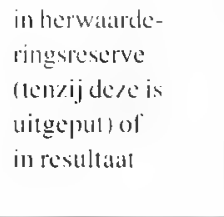 & & \\
\hline \multicolumn{7}{|l|}{$\begin{array}{l}\text { Vastrentende } \\
\text { beleggingen }\end{array}$} \\
\hline $\begin{array}{l}- \text { waladering tegen } \\
\text { kostprijs }\end{array}$ & - & - & ill restultatal & ill resultalat & in resultalal & in resultail \\
\hline 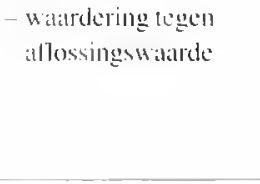 & & & $\begin{array}{l}\text { bij ruiltransaclies } \\
\text { gespreid of in- } \\
\text { eens in resultatl. } \\
\text { anders ineens } \\
\text { in resultall }\end{array}$ & $\begin{array}{l}\text { bij ruiltansicties } \\
\text { gespreid of in- } \\
\text { incens in resultaat. } \\
\text { anders incens } \\
\text { in resultatt }\end{array}$ & in resultala & in resultaill \\
\hline $\begin{array}{l}\text { - Watadering tegen } \\
\text { actuele witade }\end{array}$ & $\begin{array}{l}\text { in herwiarde- } \\
\text { gingreseserve ol } \\
\text { in resultalal }\end{array}$ & $\begin{array}{l}\text { in herwatrderings- } \\
\text { reserve (tenzij de\% is } \\
\text { uilgeput) of in resul- } \\
\text { latal (indien niel-ge- } \\
\text { real liseerde winst vial } \\
\text { resultiat loopt) }\end{array}$ & $\begin{array}{l}\text { in herwatarde- } \\
\text { ringseserve of } \\
\text { in resultail }\end{array}$ & $\begin{array}{l}\text { in herwilatede- } \\
\text { ringsereserve } \\
\text { (tenzij de\%e is } \\
\text { uitgepul) of } \\
\text { in resultatt }\end{array}$ & & \\
\hline \multicolumn{7}{|l|}{$\begin{array}{l}\text { Beleggingen voor risico } \\
\text { van polishouders en } \\
\text { spaarkasbeleggingen }\end{array}$} \\
\hline $\begin{array}{l}\text { - watardering legen } \\
\text { acluele wilarde }\end{array}$ & in resulaltalal & in resultail & in resultail & in resultatill & & - \\
\hline $\begin{array}{l}\text { - gesepillecrde beleg- } \\
\text { gingen mogen legen } \\
\text { hostprijs ol allos- } \\
\text { singswarde gewall- } \\
\text { deerd worden: }\end{array}$ & \multicolumn{6}{|c|}{ 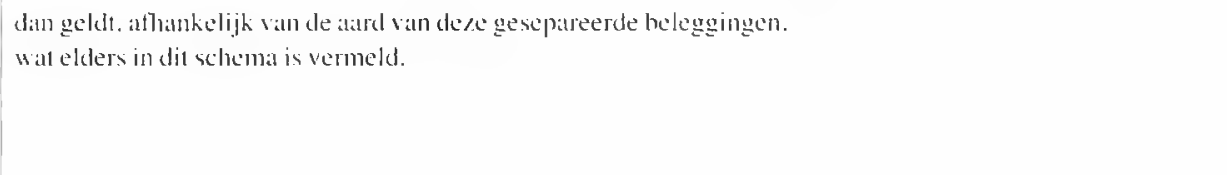 } \\
\hline
\end{tabular}

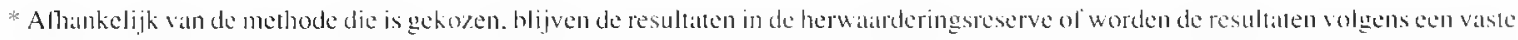
methodich getemporjseerd natas de winst- en verlicsckening overgehockl (zic alinea 217 van de ontwerp-Richelijn).

In af wijking van de wettelijke regeling, wordt hel in de herwalarderingsreserve opnemen van gerealiseerde en niet-gerealiseerde resultaten en het vervolgens via een vaste methodiek getemporiseerd naar de winst- en verliesrekening overboeken van die resultaten, atanvaardbatar geacht. ${ }^{x}$ In Oosenbrug. 1997b. is uitvoerig uileengezet dat deze methode niet kan worden geacht le leiden tol een jaarrekening die een getrouw beek geeft van de financiële positie, het vermogen en het resul- taat. Hier wordt volstatun met een verwijzing naar het aldaar gestelde." Daarbij zij crop gewezen, dat de RJ de onderhavige methode zonder meer toelaatbaar verklatart. waar zelfs de meest lervente pleitbezorgers vin deze methode de loclaatbalarheid nog beperken tot resultaten uit hoofde van beleggingen die verband houden met specifieke passiva. "Mede gezien het ontbreken van enige motivatie, blijft de grond voor deze onvoorwatardelijke acceptatic duister." 
Verzekeraars mogen - vanwege de kunstmaligheid van het onderscheid tussen gerealiseerde en niet-gerealiseerde beleggingsresultaten - ook het nog niet gerealiseerde resultaat direct in de winsten verliesrekening opnemen. Mel de alanbeveling tol het in de toelichting vermelden van het nog niet gerealiscerde deel. wordt in feite de validiteit van het door de wetgever gehanteerde kunstmatigheidsargument ontkend. Bij een werkelijk kunstmatig onderscheid past immers ook niet het maken vall dat onderscheid in de toelichting.

Indien de beleggingen worden gewaardeerd tegen actuele waarde, wordt aambevolen om in de toelichting tevens een meerjarig performanceoverzicht op te nemen. Juist bij een wiardering tegen kostprijs is het evenwel het moeilijkst om een beeld te krijgen van de perlormance. Hoewel de gegeven aanbeveling welkom is, moet op grond daarvan de beperktheid ervan worden betreurd.

Ten slotte wordt alanbevolen de resultaten op beleggingen gesaldeerd te verantwoorden, walarbij het voor rekening valn polishouders komende (saldo)resultiat separaat wordt opgenomen. Wordt deze aanbeveling opgevolgd. dan moet de samenstelling van de saldi per beleggingscategorie uit de toelichting blijken (stellige uitspraak).

\subsection{Opbrengsten wit beleggingen}

Bij het bepalen van de beleggingsopbrengsten rijst de vraag in hoeverre slockdividenden als opbrengst moeten worden verantwoord. De RJ doet de stellige uitspraak, dat dit alleen moet indien ook de mogelijkheid bestaal te opteren voor een uitkering in contanten (keuzedividend). Het gemiste contante dividend moet dan ten gunste van de winst-en verliesrekening worden gebracht. Anderszins dient geen opbrengst uit beleggingen te worden geboekt aangezien er "dan sprake is van verwatering van de waarde per aundeel en de lotale waarde van de alandelen in principe gelijk blijft ${ }^{\circ}$. Dit argument gaat uiteraard ook gedeeltelijk op voor keuzedividenden. De enige reden om dial dan toch niet dezelfde consequentie aan te verbinden. is dat de resultal verantwoording alsdan - door de keuzevrijheid - afhankelijk wordt vin de gemalakte keuze, waardoor zij manipuleerbilar wordt. Voor de duidelijkheid had dit vermeld moeten worden.

Daarnaast rijst de vraag. hoe de (krachtens artikel 2:442, vierde lid BW) aan de beleggingen in terreinen en gebouwen toe te rekenen opbrengsten moeten worden bepaald. De RJ doet de stellige uitspralak, dal de alan terreinen en gebouwen in eigen gebruik toe te rekenen opbrengsten dienen te zijn gebaseerd op een markiconforme huur.

\section{Technische voorzieningen}

\section{I Technische vorziening vor niet-verdien- de premies}

Deze voorziening betreft de al ontvangen premies ter zake van in de toekomst nog te lopen risico"s. In het algemeen zal de premieverantwoording tijdsevenredig geschieden. Kent het risico zelf echter een ongelijkmatig verloop over de tijd. dan moet de premieverantwoording daarop aansluiten (stellige uitspraak).

Voor het levensverzekeringsbedrijl wordt aanbevolen deze voorziening deel te laten uitmaken van de lechnische voorziening levensverzekering.

\subsection{Tedhische roorziening roor lopende risico's}

Deze voorziening betrelt schilden en kosten uit lopende verzekeringsovereenkomsten die niet uit nog te verantwoorden premies kumnen worden gedekt. Krachtens een stellige uitspralak wordt levens rekening gehouden met alle toekomstige gerelateerde hedrijls- en schadebehandelingskosten. De RJ heefi voorkeur voor het onder de overige technische voorzieningen opnemen van deze voorziening.

Hoewel de vergrijzingsvoorziening inzake ziekickosten- en arbcidsongeschiktheidsverzekeringen veelcer he karakter heeft van een voorziening voor niet-verdiende premies, word deze opgevoerd als voorbeeld van de voorziening voor lopende risico's.

Onder deze voorziening (of onder de overige technische voorzieningen) kan volgens de RJ een op ervaringscijfers te baseren calastrofevoorziening worden opgenomen. De omvang van deze voorziening word mede bepaald door de mate, vorm en beschikbaarheid van herverzekeringsfaciliteiten en door de tariefsophouw (beval deze een opslag voor catastrofes?). Ter voorkoming van manipulatiemogelijkheden was het beter geweest, indien er concrete richtlijnen waren gegeven voor de vorming van een dergelijke (disculabele) 
voorziening. Thans blijft dit nogal in de lucht hangen. Zo rijst de vraag of elke gebeurtenis die onevenredig veel schade veroorzaakt een catastrofe is. Daarnaast blijven de normen voor het bepalen van de omvang van de voorziening vaag. Een harde koppeling met een te hanteren premieopslag voor catastroferisico's had sterk de voorkeur verdiend. waarbij het dan meer voor de hand liggend was geweest om de voorziening op te nemen onder die voor niet-verdiende premies. Ook de rol van de herverzekeringsfaciliteiten blijft onduidelijk. Indien dit analoog aan de bepalingen omtrent de voorziening voor assurantie eigen risico moet worden geïnterpreteerd (zie $R . /$ al. 2.53.914/918), dan zouden juist de grootste catastrofes geen aanleiding geven tot het vormen van een catastrofevoorziening (in verband met het niet herverzekerbaar zijn daarvan). Moet dit anders worden geïnterpreteerd, dan leidt dit tot de merk waardige consequentie, dat er een 'sanctie' wordt geplaatst op het niet herverzekeren van herverzekerbare risico's. Dit staat gelijk aan een verbod tot het vormen van een dynamische voorziening voor debiteurenrisico's, indien die risico's verzekerbaar zijn.

Als zwak surrogaat voor concrete richtlijnen inzake de vaststelling van de catastrofevoorziening wordt de stellige uitspraak gedaan, dat de stand per balansdatum, het doel van de voorziening en de regels die gelden voor het muteren van de voorziening in de toelichting moeten worden weergegeven. Aan het tevens vermelden van het verloop van de voorziening wordt sterk de voorkeur gegeven.

\subsection{Technische voorziening voor levensverzekering}

Inzake deze voorziening doet de RJ een aantal stellige uitspraken met betrekking tot de in de toelichting op te nemen gegevens. In de toelichting worden:

- de voor de voorzieningen, de overlopende rentestandkortingen en de overlopende acquisitiekosten gehanteerde berekeningsmethoden en -grondslagen omschreven;

- de in de voorziening opgenomen en qua aard verschillende onderdelen vermeld:

- de overlopende rentestandkortingen zichtbaar op de voorziening in mindering gebracht en een verloopstaat met betrekking tot de overlopende rentestandkortingen opgenomen.
Het op actuariële wijze amortiseren van verleende rentestandkortingen verdient de voorkeur, waarbij het verloop moet blijken uit een verloopstaat (stellige uitspraak). Afhankelijk van de portefeuilleopbouw en het type verzekering kan een lineaire of een annuïtaire afschrijving daarvoor een goede benadering zijn, aldus de RJ. Inzake een lineaire afschrijving is het de vraag in hoeverre dit vaker dan puur incidenteel ook daadwerkelijk het geval zal zijn.

Binnen dit kader worden de door de VK in een beleidsnota vastgelegde 'Actuariële principes' aangehaald, zonder dat de status daarvan overigens duidelijk wordt. Bovendien is daarbij kennelijk over het hoofd gezien, dat de daarin opgenomen bepalingen omtrent de maximering van de rekenrente inmiddels zijn achterhaald door de Regeling maximum rentepercentages.

De uit de Actuariële principes overgenomen regel dat een negatief saldo van de voorziening en de geactiveerde acquisitiekosten op nul moet worden gesteld, is in strijd met de bedrijfseconomische activeringscriteria en met de nadrukkelijk door de wet geboden mogelijkheid tot het activeren van acquisitiekosten.

\subsection{Technische voorziening voor te betalen schaden of yoor te betalen witkeringen}

In deze voorziening moeten mede de schadebehandelingskosten worden opgenomen. Deze worden bepaald op basis van de gemiddelde afwikkelingstermijnen per soort schade, rekening houdend met alle toekomstige en voor inflatie gecorrigeerde kosten (stellige uitspraak).

Voor het levensverzekeringsbedrijf wordt aanbevolen de voorziening onderdeel te laten uitmaken van de technische voorziening levensverzekering.

Verder worden voornamelijk uitspraken gedaan omtrent de in de toelichting op te nemen gegevens.

\subsection{Technische voorzieningen buitenlandse groepsmaatschappij}

Mag een buitenlandse groepsmaatschappij niet afwijken van lokale waarderingsvoorschriften, dan mag de in beginsel noodzakelijke uniformering van grondslagen voordat tol consolidatie wordt overgegaan $^{2}$, achterwege worden gelaten (artikel 
2:446, derde lid BW). De RJ beperkt met een stellige uitspraak de reikwijdte van deze op zich vreemde bepaling tot situaties waarin de lokaal voorgeschreven grondslagen niet wezenlijk afwijken van de groepsgrondslagen. Mede gezien het materialiteitsbeginsel, wordt de praktische relevantie van de wettelijke bepaling daarmee in feite gereduceerd tot nihil. Een naar analogie van artikel 2:410, vierde lid BW opgezette richtlijn (consolidatie overeenkomstig buitenlands recht met een uiteenzetting van de invloed daarvan op vermogen en resultaat) had beter recht gedaan aan de strekking van de expliciete wettelijke bepaling.

Het is niet duidelijk waarom er met betrekking tol de beleggingen voor risico van uitkeringgerechtigden niet eenzelfde uitspraak is opgenomen (vergl. artikel 2:446, vierde lid $B W$ ).

\section{Eigen vermogen}

Verzekeringsmaatschappijen zijn op grond van de WTV 1993, respectievelijk de WTN, onderworpen aan bepaalde solvabiliteitseisen, waardoor een deel van het eigen vermogen niet-uitkeerbaar is. In de verslagstaten moet informatie worden verstrekt over de hoogte van de vereiste en de aanwezige solvabiliteitsmarge, onder andere door vermelding daarvan in de toelichting op het eigen vermogen. Aanbevolen wordt deze informatie ook in de jaarrekening op te nemen. Gezien het belang van deze informatie voor de beoordeling van de financiële positie van de verzekeraar (niet alleen het weerstandsvermogen, maar ook de groeicapaciteit en zelfs de continuïteit van de verzekeraar zijn hiervan afhankelijk!), is het een goede zaak dat dit manco in de BW-regelgeving nu in ieder geval door middel van een richtlijn wordt gedicht. Gegeven het belang van deze informatie, is het overigens wel wenselijk dat deze aanbeveling in de definitieve richtlijn de status van stellige uitspraak krijgt.

\section{Baten en lasten}

\section{I Afbakening van de baten}

Hoewel de omzet van een onderneming feitelijk hét vertrekpunt is voor het geven van inzicht in de (financiële) ontwikkeling daarvan (zonder omzet geen ondememing), geeft de wet op geen enkele wijze aan wat bij verzekeraars onder de omzet moet worden verstaan. De ontwerp-Richtlijn geeft een eerste, heel voorzichtige aanzet om te voorzien in dit manco. Met de stellige uitspraak dat moet worden vermeld wat onder de omzet wordt verstaan ${ }^{13}$, indien een (netto)omzetbegrip wordt gehanteerd. laat de RJ echter nog wel de mogelijkheid open dat het geven van inzicht in de omzet in het geheel wordt vermeden. Ondanks het feit dat er nog wel wat haken en ogen zitten aan het definiëren van een omzetbegrip voor verzekeraars, valt het te betreuren dat nog steeds de mogelijkheid wordt opengelaten om dit probleem dan maar geheel te omzeilen. De totstandkoming van de ontwerp-Richtlijn was juist een mooie aanleiding geweest om tot een meer concrete eerste aanzet te komen.

Voor wat betreft de al dan niet tot de premieinkomsten te rekenen posten doet de RJ wel een aantal concrete stellige uitspraken:

- premie-opslagen voor termijnbetalingen en bijkomend aan verzekeringnemers in rekening gebrachte kosten (zoals poliskosten) worden tot de brutopremies gerekend;

- kortingen die deel uitmaken van een op de aard van het risico afgestemd tarief (no-claim- of bonuskortingen) worden op de brutopremies in mindering gebracht ${ }^{\text {t4; }}$;

- assurantiebelasting en wettelijke (omslag)bijdragen horen niet tot de premies (verbazingwekkend genoeg geen stellige uitspraak);

- op grond van poolovereenkomsten ontvangen vergoedingen uit centrale kassen worden in de technische rekening schadeverzekering als afzonderlijke post verantwoord onder de premies;

- bij levensverzekering omvatten de premies ineens tevens de lijfrentekoopsommen en de koopsommen uit winstdeling.

Voor wat betreft dit laatste punt moet worden opgemerkt, dat hiermee het in de praktijk ontstane gebruik om het omzetcijfer flink op te kloppen (door het als omzet verantwoorden van winstdelingskoopsommen), helaas wordt bestendigd.

Reeds als beleggingsopbrengsten in de omzet opgenomen bedragen worden daarmee nogmaals, maar nu als premie, als omzet verantwoord. Voor een getrouw beeld van de omzet moet het omzetcijfer dan ook juist worden geschoond van winstdelingskoopsommen. Hetzelfde geldt voor verleende rentestandkortingen (zie Oosenbrug, 1995a, paragraaf 3.5 ), waaromtrent hier overigens niets wordt vermeld. 


\subsection{Schaden e'n witkeringe'n oigen rekening}

Ook op het punt van de vaststelling van de schadevoorziening schict de huidige wet-en regelgeving tekort mel de weinig concrete bepaling dal er sprake moel zijn van 'voor de bedrijfslak aanvaardbare grondslagen" (artikel 2:444. eerste lid BW). "Objectieve methoden ter bepaling van de IBNR-en de IBNER-voorziening ${ }^{15}$ zouden moeten worden voorgeschreven. (...) Een verplichting lot hel geven van cen gedetailleerder inzicht in de uilloop van oude bockjaren is één van de eerste vereisten om een beeld tc kunnen krijgen van de kwaliteit van de vaststelling van de schadevoorziening.' (Oosenhrug. 1995h, p. 10). Het eerstgenoemde punt is vooralsnog niet opgepaki door de RJ: voor wat betreli hel lweede punt beperkt de RJ zich tot het interpreteren en kwanlificeren van het in artikel 2:439. zesde lid BW bepaialde.

Krachtens artikel 2:439, zesde lid BW moet de schade-uitloop worden vermeld, tenzij deze op het geheel ran toe- of afneming van de voor-iening van ondergeschikte hetekenis is. Voor de bepaling van de materialiteil moel op grond van de wettekst dus worden gekeken nalar de verhouding tussen de uitloop en de mutatie van de voorziening. De MvT vermeldt hieromtrent: 'Als deze wijzigingen over het geheel van de voorziening genomen niet van ondergeschikte betekenis zijn. moet de aard en omvang van het verschil tussen het begin en het einde van het boekjalar in de toelichting worden angegeven. " De RJ interpreteerl dit in die zin, dal het uitgangspunt voor de toets wordt gevonden in de stand van de voorziening aan het eind van het voorgaande bockjaar (RI, al. 3.23.616). Daarmee wordt gekozen voor een interpretatie die in strijd is met de wettekst. Een wel in lijn met de wettekst liggende. en dus meer voor de hand liggende interpretatie is die. walin de woorden "over het geheel van de voorziening genomen " worden geacht aan te geven dal de bedoelde toets op het niveau van de totale voorziening mag worden uitgevoerd. Dit sluit ook alan op het in de wet bepalalde. dat de toets zich dient te richten op het gehee/ van de mutatie.

De aanbeveling dat de schade-uitloop niel van ondergeschikte betekenis moet worden geacht. indien deze voor alle branches tezamen en per saldo meer bedraagt dan 10\% van de op voorgaande jaren betrekking hebbende schadevoorziening. moet op grond van het vorenstainde aldus worden gecorrigeerd. dat niet de omvang van de schadevoorziening. maar de mutatie daarvan het referentiepunt vormt. In het algemeen leidt dit tot het aanzienlijk sneller 'material' zijn van de schadeuitloop. Gezien het weinigzeggende karakter viun een gesaldeerde totaalpost, zou dan tevens de aimbeveling moeten worden toegevoegd tot het in alanvulling op de wettelijke eis - geven van meer gedetailleerde informat ie omtrent de uitloopcijfers.

\subsection{Winstdeling en kortingen}

Omtrent de post Winstdeling en kortingen doet de RJ de voor de hand liggende stellige uitspralak. dat ook de afschrijving rentestandkortingen daaronder moet worden opgenomen. Vreend genoeg wordt tegelijkertijd echter impliciet gesteld, dat verleende rentesiandkortingen ook direct kunnen worden afgeboek 1 . De resulterende strijdigheid met het matchingheginsel moet zonder meer onaanvaardbaar worden genoemd. De weten regelgeving biedt ook geen enkel aanknopingspunt voor het als alanvialrdbalar alanduiden van een dergelijke verantwoordingswijze. Ten slotte zij erop gewezen. dat het ook binnen het kader van de traditionele verslaggevingsusances al algemeen gebruikelijk was om verleende rentestandkortingen te activeren.

\section{7.t Kosten}

De acquisitiekosten omvalten:

- alsluit- en verlengingsprovisie, personeelskosten loondienstagenten en aambrengprovisie betaald aan personeel:

- kosten van medische keuring:

- kosten van aanvragen en van het opmaken van polissen. alsmede administratiekosten voor het in de portefeuille opnemen daarvan;

- reclame-en marketingkosten.

en alle andere kosten die direct of indirect te maken hebben met het sluiten van een verzekering. Hiermee wordt nader inhoud gegeven alan het in artikel 2:440. tweede lid BW gestelde. dat de acquisitiekosten bestaan uit de middellijk of onmiddellijk met het sluiten van verzekeringsovereenkomsten samenhangende kosten. De stellige uitspraak, dat de diverse soorten kosten moeten worden bepaald op basis van een integrale kostentoerekening van de desbetreffende afdelingen. heeft ook hierop betrekking. Gegeven de thans gangbare wijzen van vaststelling van de acquisi- 
tiekosten. zal het nog de nodige voeten in de aarde hebben voordat in de praktijk aan deze aanbeveling zal (kunnen) worden voldaan.

Het verdient aanbeveling de acquisitiekosten op zodanige wijze aan de opeenvolgende jaren toe te rekenen, dat - rekening houdend met de aard valn de polis - een goede matching ontstaat met de ermee in verband staande balten.

\section{Overige onderwerpen}

\section{I Herverzekering}

Met de stellige uitspraak, dat herverzekeringsovereenkomsten moeten worden verantwoord als financieringsovereenkomst indien er geen sprake is van substantiële risico-overdracht, wordt keihard afgerekend met financiële herverzekeringsconstructies zoals deze bijvoorbeeld in het kader van de Vie d'Or-case werden toegepast.

\subsection{Kasstroomoverzich}

Gezien de mogelijk veel voorkomende vermogensmutaties ( $R J$, al. 3.23.703), is opneming van een kasstroomoverzicht mede relevant voor verzekeraars. Hoewel de algemene richtlijnen dienaangaande nauwelijks toepasbaar zijn voor verzekeraars. en er ook pas te zijner tijd aandacht zal worden besteed aan de praktische toepassing diarvan bij verzekeraars. worden deze wel al direct op verzekeraars van toepassing verklaard. Dit van toepassing verklaren van bepalingen zonder dat eerst aandacht is geschonken aan de praktische toepasbaarheid ervan, kan nauwelijks serieus worden genomen.

\subsection{Geconsolideerde jaarrekening}

De wettelijke bepaling inzake het overeenkomstig de voorschriften voor banken meeconsolideren van een tot een verzekeringsgroep behorende bank (artikel 2:445, eerste lid BW) is volgens de $R . /$ al. 3.23 .705 , alleen van tocpassing indien een groep overwegend verzekeringsictiviteiten heeft en datrnaast in relatief beperkte mate bankactiviteiten.

Bevat de geconsolideerde jaarrekening van een niet-verzekeraar ${ }^{16}$ voor een belangrijk deel de financiële gegevens van verzekeraars, dan wordt alanbevolen het te geven inzicht in de financiële gegevens van de verzekeralars als één geheel ook met betrekking tot de winst- en verliesrekening zoveel mogelijk in overeenstemming met de vormvoorschriften voor verzekeralars te doen platatsvinden. Voor wat betreft de balans is dit al in de wet zelf geregeld (artikel 2:406, zesde lid BW). Tevens wordt aanbevolen het te geven inzicht in het eigen vermogen van de banken respectievelijk de verzekeraars als één geheel te verstrekken door de in de toelichting op te nemen geconsolideerde balans uit te splitsen naar bancairc activiteiten, verzekeringsactiviteiten en eventuele overige activiteiten.

\section{Besluit}

De wet- en regelgeving met betrekking tot de verslaggeving van verzekeraars vormt een complexe materie. waar bovendien nog de nodige open einden in zijn te onderkennen. Het moet dan ook worden toegejuicht. dal de RJ een eerste voorzet heeft gedaan voor het interpreteren en het nader concretiseren van die wet- en regelgeving. Gezien de complexiteit van de onderhavige materie, is het niet verbazingwekkend dat de gegeven voorzet ook de nodige kritiek uitlokt. maar daarvoor is het ook nog slechts een (mitwerp-Richtlijn!

Gegeven de omvang van de ontwerp-Richtlijn was het onmogelijk deze integraal en in detail te behandelen. Aan die (grote) delen van de ontwerpRichtlijn, waarin direct uit de wet- en regelgeving voortvloeiende bepalingen zijn opgenomen, is zonder meer geen alandach besteed. In feite is daardoor enkel ingegalan op de echt als nieuw te beschouwen 'nomen'. Voor een meer algemeen overzicht van de voor verzekeraars geldende verslaggevingsvoorschrilten wordt verwezen naar Coopers \& Lybrand (1997).

In een kritische bespreking overheerst al snel de kritiek. Tot besluit is het dan ook een goede zaak te benadrukken dat met het totstandbrengen van de ontwerp-Richtlijn een omvangrijke en complexe klus is geklatard om een goed fundament te leggen voor de verdere ontwikkeling van een verantwoord en compleet bouwwerk van normen en richtlijnen. Dat de voorgainde kritische beschouwing daaraan mag bijdragen. 


\section{LITERATU U R}

Aegon Verzekeringen, (1996), Jaarverslag 1995. Aegon N.V., 's-Gravenhage.

Beckman, H., (1996a), Het AEGON-systeem van resultaatverantwoording op beleggingen: verantwoord dan wel ongeoorloofde winstegalisatie?, Het Verzekerings-Archief nr. 73-1996-4, pp. 150-153.

Beckman, H., (1996b), 'Substance over form': verslaggevingsnut of -ongemak?, fma-kroniek 1996 (red.: C.M.T. Boneco e.a.), Samsom, Rotterdam 1996.

Coopers \& Lybrand, (1997), Verzekeringsmaatschappiien: vers/aggeving en toezicht (red.: L. Slingerland e.a.), Coopers \& Lybrand, Amsterdam.

Geljon, P.A., (1994), Jaarvers/aggeving van Nederlandse banken, Nederlands Instituut voor het Bank- en Effectenbedrijf, Amsterdam

Kruisbrink, K., (1984). The responsibility of the actuary and his relationship to the auditor in general insurance, Proceedings of the 4 countries Astin-symposium. Astin-Groep Nederland, Akersloot, pp. 253-260.

Oosenbrug, A., (1986), 'Generally Accepted Accounting Principles' versus 'Statutory Accounting Practices' bij levensverzekeringsmaatschappijen in de USA - 1, Het Verzekerings-Archief, nr. 63-1986-3, pp. 201-210

Oosenbrug, A., (1990), Verslaglegging inzake ruiltransactieresultaten bij vastrentende beleggingen, Maandblad voor accountancy en bedriifseconomie, 64e jaargang, maart, pp. $62-77$.

Oosenbrug, A., (1993), Levensverzekeraar en vennootschapsbelasting: de voorziening verzekeringsverplichtingen binnen de fiscale resultaatbepaling, Gouda Quint BV, Arnhem

Oosenbrug, A., (1995a), Externe verslaggeving door levensverzekeraars, Delwel Uitgeverij BV, 's-Gravenhage.

Oosenbrug. A., (1995b), Actuariële principes bedrijfseconomisch beschouwd: over achtergrond, strekking en bereik van de actuariële principes, Symposiumbundel MEY. verzekeringsdag 1995, Moret Ernst \& Young, 's-Gravenhage.

Oosenbrug, A., (1997a), Achtergrond, structuur en inhoud van de waarderingsvoorschriften inzake verzekeringstechnische voorzieningen, Maandblad voor accountancy en bedrijfseconomie, 71e jaargang nummer $1 / 2$, januari/ februari, pp. $7 / 18$

Oosenbrug, A., (1997b), Spreiding van beleggingsresultaten onaanvaardbaar!?!, Het Verzekerings-Archief nr. 74-19971. pp. 2-10

Raad voor de Jaarverslaggeving, Richtliinen voor de jaarverslaggeving vanaf 1990, Kluwer Bedrijfswetenschappen, Deventer, losbl.
Verzekeringskamer, (1994), Actuariële principes, beleidsnota d.d. augustus 1994, Verzekeringskamer, Apeldoorn.

Wijk, H.B. van \& J. de Boer, (1995), Nieuw winstbegrip in het levenbedrijf, Maandblad voor accountancy en bedriffseconomie 69e jaargang, november, pp. 717-720.

\section{NOTEN}

1 Wet toezicht verzekeringsbedrijf 1993.

2 Een verzekeringsgroep(sdeel) is een groep(sdeel) welke geen of nagenoeg geen andere werkzaamheid heeft dan de uitoefening van het verzekeringsbedrijf.

3 Aangezien in al. 3.23.103, slot nadrukkelijk wordt gerefereerd aan de Wet toezicht natura-uitvaartverzekerings bedrijf (WTN), moet worden aangenomen dat het enkel een redactionele omissie is dat in al. 3.23.109 en 110 geen rekening is gehouden met de onder de WTN vallende verzekeraars en met de specifiek op hen van toepassing zijnde toezichtsbepalingen. Hetzelfde geldt voor al. 3.23.201, 225, 401, 504, 509,510 en 518.

4 Deze aanbeveling leidt overigens tot de volgende ongelukkige formuleringen: 'in het geval dat naast de verslagstaten een jaarrekening volgens Boek 2 BW wordt gepubliceerd (...)' (al. 3.23.225) en 'indien gekozen is voor afzonderlijke publicatie van de jaarrekening volgens Titel 9 Boek 2 BW' (al. 3.23.401). Voor wat betreft de publicatie van de jaarrekening heeft men niets te kiezen!

5 Hetzelfde geldt uiteraard voor participaties in andersoortige beleggingsinstellingen die niet het risico/rendementsprofiel van aandelenbeleggingen hebben, zoals participaties in instellingen die beleggen in obligaties of die beleggen in edele metalen

6 Is er geen sprake van een ruiltransactie, dan wordt het verkoopresultaat ineens als resultaat genomen.

7 De rendementswaarde is de contante waarde van de nog te ontvangen rente- en aflossingsbedragen, waarbij de discontering geschiedt tegen de marktrente op de balansdatum.

8 Volgens de tekst van de ontwerp-Richtlijn heeft dit betrekking op tegen actuele waarde gewaardeerde beleggingen, ongeacht de aard daarvan. Uit de desbetreffende bijlage kan evenwel worden afgeleid dat dit uitsluitend betrekking heeft op beleggingen in terreinen en gebouwen en in aandelen, en dus niet op beleggingen in vastrentende waarden. Wat nu uiteindelijk de intentie van de $\mathrm{R} J$ is geweest, laat zich slechts raden.

9 Voor pleidooien voor de aanvaardbaarheid van deze methode zij bijvoorbeeld verwezen naar Beckman, 1996a, en Van Wiik \& De Boer, 1995

10 Aegon heeft aangekondigd op praktische gronden de toepassing van de bedoelde methode te zullen gaan uitbreiden. 
11 De door Beckman, 1996b, p. 11, geleverde kritiek, dat het een fundamenteel gebrek van de huidige werkwijze van de $\mathrm{RJ}$ is dat stelligheden zonder motiveringen worden gedebiteerd, is in beginsel net zo goed van toepassing op de niet als stellige uitspraak gedane aanbevelingen.

12 De stelling dat de noodzaak tot uniformering van grondslagen valt af te leiden uit artikel 2:410, derde lid BW, geeft niet op de meest voor de hand liggende wijze onderbouwing aan de eis tot uniformering. Artikel 2:410, derde lid BW ziet op de verhouding tussen de in de enkelvoudige en de in de geconsolideerde jaarrekening gehanteerde grondslagen en niet op de 'interne' consistentie van de binnen de (al dan niet geconsolideerde) jaarrekening gehanteerde grondslagen. Dit laatste volgt slechts op indirecte wijze uit het eerste, terwijl dit wel op directe wijze kan worden afgeleid uit het in artikel
2:385, eerste lid BW bepaalde (activa en passiva worden enkel afzonderlijk gewaardeerd, voor zover zij in hun betekenis voor het in artikel 2:362, eerste lid BW bedoelde inzicht verschillen).

13 In al. 3.23.607 gooit de RJ overigens zelf de begrippen 'omzet' en 'premie-inkomen' door elkaar.

$14 \mathrm{Er}$ moet worden aangenomen dat (malus) toeslagen dan als negatieve (bonus)kortingen moeten worden verwerkt.

15 IBNR staat voor 'incurred but not reported' en IBNER voor 'incurred but not enough reported'.

16 Voor de invulling van het begrip Verzekeraar wordt verwezen naar artikel 2:427, eerste lid BW. De in de ontwerp. Richtlijn gesignaleerde fout dat in de oorspronkelijke wettekst werd verwezen naar het achterhaalde artikel 2:399 BW is overigens al gecorrigeerd. 